\title{
Penerapan Algoritma C4.5 Dalam Mengklasifikasi Status Gizi Balita Pada Posyandu Desa Dames Damai Kabupaten Lombok Timur
}

\author{
Mahfuz $^{1 *}$, Amri Muliawan Nur², L M Samsu \\ 1 Program Studi Teknik Informatika, Universitas Hamzanwadi \\ 2,3 Program Studi Sistem Informasi, Universitas Hamzanwadi \\ *mahfuzuma@gmail.com
}

\begin{abstract}
Abstrak
Gizi merupakan hal yang sangat penting bagi pertumbuhan manusia terutama pada balita. Kekurangan maupun kelebihan asupan zat gizi pada balita dapat mempengaruhi status gizi dan status kesehatannya. Anak yang memiliki status gizi buruk akan mengalami penurunan daya tahan tubuh dan rentan terhadap penyakit. Adapun permasalah pada Posyandu Desa Dames Damai yaitu laporan data balita disimpan dalam buku catatan yang berisi data balita beserta hasil penimbangan yang dilaksanakan setiap bulan. Namun, data tersebut hanya menjadi tumpukan di rumah kader-kader. Perlu adanya pengolahan data yang nantinya akan menghasilakan informasi yang bermanfaat bagi pihak posyandu. Algoritma C4.5 merupakan teknik klasifikasi yang digunakan dalam penelitian ini yang terdiri dari 4 atribut yang dipakai dalam pengklasifikasian yaitu jenis kelamin, umur, berat badan dan tinggi badan. Memperoleh hasil akurasi yang diperoleh sangat baik atau cukup sempurna yaitu $97.02 \%$ sedangkan nilai AUC yang diproleh dari decision tree 0.928
\end{abstract}

Kata Kunci : Gizi, Algoritma C4.5, Data minig

\begin{abstract}
Nutrition is very important for human growth, especially in toddlers. Lack of or excess intake of nutrients in toddlers can affect nutritional status and health status. Children who have poor nutritional status will experience a decrease in body resistance and are susceptible to disease. The problem with Posyandu in Dames Damai Village is that toddler data reports are stored in a notebook containing toddler data along with the results of weighing which is carried out every month. However, the data only becomes a pile in the houses of the cadres. There is a need for data processing which will later produce useful information for the posyandu. The C4.5 algorithm is a classification technique used in this study which consists of 4 attributes used in the classification, namely gender, age, weight and height. The accuracy results obtained are very good or quite perfect, namely $97.02 \%$ while the AUC value obtained from the decision tree is 0.928
\end{abstract}

Keywords : Nutrition, C4.5 algorithm, Data minig

\section{Pendahuluan}

Posyandu adalah pemeriksaan serta pemantauan gizi pada balita karena merupakan salah satu pelayanan yang di fasilitasi oleh pemerintah Sebagai upaya untuk meningkatkan kemampuan masyarakat agar dapat hidup sehat [1]. Menurut
Peraturan Pemerintah RI Nomor 17 Tahun 2015 Gizi adalah zat atau senyawa yang terdapat dalam pangan yang terdiri dari karbohidrat, protein, lemak, vitamin, mineral, serat, air, dan komponen lain yang bermanfaat bagi pertumbuhan dan kesehatan manusia terutama 
pada balita [2]. Pengukuran antropometri, antropometri adalah pengukuran yang digunakan untuk menentukan keadaan gizi balita. Parameter gizi yang meliputi penilaian terhadap usia dan berat badan, dan panjang badan, atau tinggi badan. akan tetapi, data-data gizi balita menjadi sulit untuk diklasifikasikan karena banyaknya jumlah balita [3]. Tujuan pengukuran antropometri agar mengetahui balita yang memiliki gizi normal dan tidak normal.

Gizi buruk merupakan resiko yang biasanya terjadi pada anak balita. Anak balita merupakan kelompok umur yang rawan terhadap gangguan kesehatan dan gizi.. Anak yang gizi buruk akan mengalami penurunan daya tahan sehingga anak rentan terhadap penyakit infeksi. Masalah tersebut banyak di temukan pada beberapa posyandu, salah satunya pada posyandu di Desa Dames Damai. Posyandu ini menyimpan laporan data balita dalam buku catatan yang berisi data balita beserta hasil penimbangan yang dilaksanakan setiap bulan. Namun, data tersebut hanya menjadi tumpukan di rumah kader-kader. Perlu adanya pengolahan data yang nantinya akan menghasilakan informasi yang bermanfaat bagi pihak posyandu. Mengingat pentingnya pengolahan data tersebut, dibutuhkan teknik pengolahan data menggunakan prinsip data mining yang efektif danefisien agar resiko gizi buruk tidak terjadi.

Dalam penelitian ini menggunakan Algoritma C4.5 dalam klasifikasi data dengan teknik pohon keputusan yang terkenal dan disukai karena memiliki kelebihan-kelebihan. Kelebihan ini misalnya dapat mengolah data numerik (kontinyu) dan diskret, dapat menangani nilai atribut yang hilang, menghasilkan aturan-aturan yang mudah diintrepetasikan dan tercepat diantara algoritma algoritma yang lain. Keakuratan prediksi yaitu kemampuan model untuk dapat memprediksi label kelas terhadap data baru atau yang belum diketahui sebelumnya dengan baik[2].

\section{Tinjauan Pustaka}

\subsection{Penelitian Terkait}

Ada beberapa penelitian yang sudah dilakukan sebelumnya yang terkait dengan penelitian ini antara lain:

"Optimasi Klasifikasi Status Gizi Balita Berdasarkan Indeks Antropometri Menggunakan Algoritma C4.5 Adaboost Classification". Dimana pada umur tertentu berat badan bayi harus sesuai umurnya, sedangkan pada saat perhitungan terkadang berat badan bayi tidak sesuai umur yang ada di real dataset hingga klasifikasi hanya mencapai 89,53\%. Setelah data diberi teknik adaboost, ketidak seimbangan data bisa diatasi, dimana data sesuai dengan standar peraturan antropometri dan menghasilkan akurasiklasifikasi yang meningkat sebesar $90,23 \%$. Untuk itu padaakhir penelitian disimpulkan bahwa algoritma C4.5 AdaBoostada peningkatan akurasi klasifikasi status gizi balita disbanding C4.5 [4]. 
"Komparasi Algoritma C4.5 Dan Backpropagation Untuk Klasifikasi Status Gizi Balita Berdasarkan Indeks Antropometri Bb/U Dan BB/PB". Berdasarkan hasil uji coba yang dilakukan maka dapat disimpulkan bahwa model algoritma backpropagation mampu mengklasifikasikan status gizi balita dengan tingkat akurasi yang lebih tinggi dibandingkan algoritma $\mathrm{C} 4.5$ yaitu sebesar 96,08\% dan kappa memperoleh hasil yang excellent yaitu sebesar 0,907 . Sedangkan hasil uji mnggunakan Algoritma C4.5 diperoleh akurasi sebesar 88,24\% dan kappa sebesar 0,725 [5].

"Klasifikasi Tingkat Pengetahuan Ibu Dalam Pemberian Asi Eksklusif Menggunakan Algoritma Decision Tree C4.5 Berbasis PSO".Penelitian ini dilakukan dengan menggunakan aplikasi rapidminer serta menggunakan sampel data keseluruhan yaitu sebanyak 250 data responden serta melibatkan semua atribut yang ada, pengujian dengan menguji nilai validasi mulai dari 2 sampai dengan 10, pada pengujian ini algoritma C4.5 yang menjadi akurasi terbaik adalah nilai validasi $=6$ dengan akurasi $61.61 \%$, sedangkan untuk algoritma C4.5 + PSO menghasilkan akurasi $69.20 \%$ di validasi $=10$. Jadi selisih antara algoritma C4.5 + PSO mengalami kenaikan sebesar $7.59 \%$ [6].

"Sistem Pakar Pendeteksi Gizi Buruk Pada Anak Menggunakan Metode Decission Tree C4.5". Berdasarkan pembahasan yang telah dilakukan dengan algoritma Decision tree maka dapat disimpulkan bahwa hasil perhitungan dengan algoritma decision treemampu digunakan untuk menentukan status gizi buruk anak, dengan tingkat keakurasian mencapai 75\% [7].

\subsection{Landasan Teori}

1. Data Mining

Data mining adalah sebuah metode penambangan data yang menemukan pengetahuan dari data yang informasinya masih tersembunyi. Jumlah data yang disimpan oleh suatu organisasi bertambah dengan pesat. Jumlah data meningkat dari tahun ke tahun dan mungkin ada pembayaran dalam mengungkap informasi tersembunyi di balik data yang ada [8].

Berikut ini adalah gambar tahapan data mining [9].

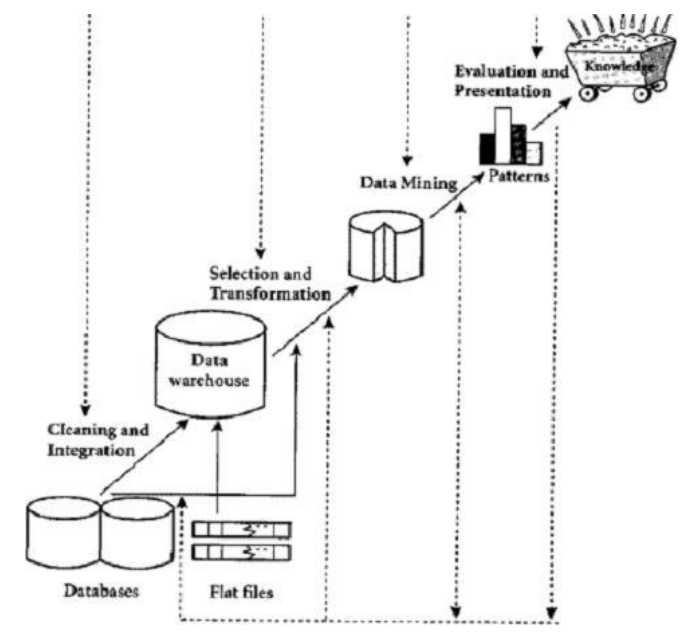

Gambar 1. Tahap Tahap Data Mining

a. Pembersihan data (data cleaning)Pembersihan data merupakan proses menghilangkan noisedan data yang tidak konsisten atau data tidak relevan.

b. Integrasi data (data integration) 
Integrasi data merupakan penggabungan data dari berbagai databaseke dalam satu databasebaru.

c. Seleksi data (data selection)

Data yang ada pada databasesering kali tidak semuanya dipakai, oleh karena itu hanya data yang sesuai untuk dianalisis yang akan diambil dari database.

d. Transformasi data (data transformation) Data diubah atau digabung ke dalam format yang sesuai untuk diproses dalam data mining.

e. Proses mining

Merupakan suatu proses utama saat metode diterapkan untuk menemukan pengetahuan berharga dan tersembunyi dari data.Baitul Maal wa Tamwil adalah balai usaha mandiri terpadu yang isinya berintikan bayt al-maal wa altamwil dengan kegiatan mengembangkan usaha-usaha produktif dan investasi dalam meningkatkan kualitas kegiatan ekonomi pengusaha kecil bawah dan kecil dengan antara lain mendorong kegiatan menabung dan menunjang pembiayaan kegiatan ekonominya.

f. Evaluasi pola (pattern evaluation)

Untuk mengidentifikasi pola-pola menarik ke dalam knowledgebasedyang ditemukan.

g. Presentasi pengetahuan

Merupakan visualisasi dan penyajian pengetahuan mengenai metode yang digunakan untuk memperoleh pengetahuan yang diperoleh pengguna.

2. Klasifikasi

Klasifikasi data adalah suatu proses yang menemukan properti-properti yang sama pada sebuah himpunan obyek di dalam sebuah basis data dan mengklasifikasikannya ke dalam kelaskelas yang berbeda menurut model Klasifikasi yang ditetapkan. Tujuan dari klasifikasi adalah untuk menemukan model dari trainingsetyang membedakan atribut ke dalam kategori atau kelas yang sesuai, model tersebut kemudian digunakan untuk mengklasifikasikan atribut yang kelasnya belum diketahui sebelumnya. Teknik klasifikasi terbagi menjadi beberapa teknik yang diantaranya sebagai berikut [10].

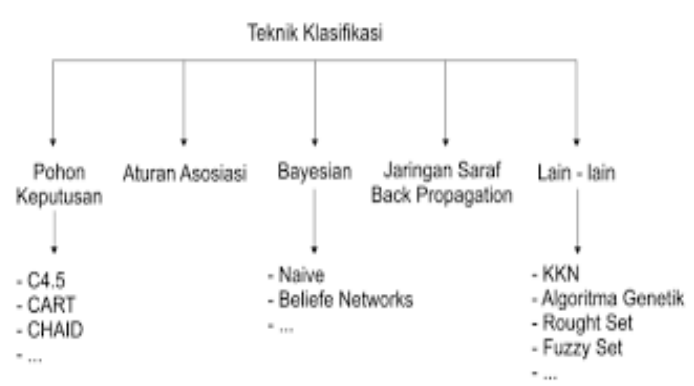

Gambar 2. Teknik Klasifikasi

3. Pohon Keputusan (decision tree)

Decicion tree merupakan salah satu metode klasifikasi yang sangat menarik yang melibatkan konstruksi pohon keputusan yangterdiri dari node keputusan yang di hubungkan dengan cabangcabang dari simpul akar sampai ke node daun (akhir). Pada node keputusan atribut akan diuji, dan setiap hasil akan menghasilkan cabang. Setiap cabang akan diarahkan ke node lain atau 
ke node akhir untuk menghasilkan suatu keputusan. Pohon keputusan biasanya digunakan untuk mendapatkan informasi untuk tujuan pengambilan sebuah keputusan [11].

\section{Algoritma C4.5}

Algoritma yang dapat digunakan untuk memprediksi atau mengklasifikasi suatu kejadian dengan pembentukan pohon keputusan antara lain algoritma C4.5, yang merupakan salah satu algoritma induksi pohon keputusan yang dikembangkan oleh J.Ross Quinlan. Algoritma C4.5 merupakan kelompok algoritma decision tree. Algoritma ini mempunyai input berupa training samples dan samples. Training samples merupakan data contoh yang digunakan untuk membangun sebuah tree yang telah diuji kebenarannya. Sedangkan samples merupakan field-field data yang digunakan sebagai parameter dalam klasifikasi data [9].

\section{Gizi}

Gizi merupakan suatu proses organisme menggunakan makanan yang dikonsumsi secara normal melalui digesti, absorpsi, transportasi, penyimpanan, dan pengeluaran zat-zat yang tidak digunakan untuk mempertahankan kehidupan, pertumbuhan dan fungsi normal dari organ-organ, serta menghasilkan energi [12].

\section{RapidMiner}

RafidMiner merupakan software yang berdiri sendiri untuk analisis data dan sebagai mesin data mining yang dapat diintegrasikan pada produknya sendiri. RafidMiner ditulis dengan menggunakan Bahasa java sehingga dapat bekerja di semua sistem operasi. Tujuan analis rafidminer adalah untuk mendapatkan informasi bermutu tinggi dari data yang diolah, dan untuk mengetahui tingkat akurasi yang lebih baik [13].

\subsection{Tahapan Penelitian}

Adapun tahapan dari penelitian ini meliputi beberapa tahapan diantaranya:

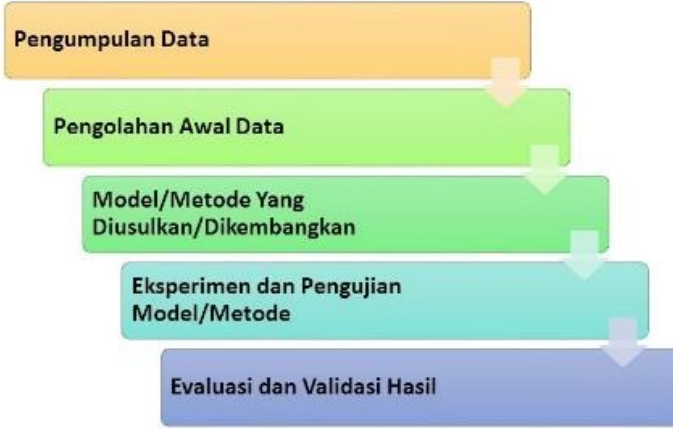

Gambar 3. Tahapan Penelitian

1. Pengumpulan Data

Pada tahap ini ditentukan data yang akan diproses. Mencari data yang tersedia, memproleh data tambahan yang dibutuhkan, mengintegrasikan semua data kedalam data set, termasuk variable yang diperlukan dalam proses.

2. Pengolahan Data

Data set yang akan digunakan diolah terlebih dahulu. Data set yang digunakan dipilih berdasarkan atribut yang diperlukan dengan seleksi atribut.

3. Model Yang Diusulkan

Menggambarkan alur metode yang diusulkan serta menjelaskan cara kerja model yang diusulkan. Metode ini akan digambarkan 
secara skematik dan disertai dengan formula

perhitungan. Model akan dibentuk dari data yang sudah diolah, dan hasil pengolahan model akan diukur dengan model yang ada saat ini. Kemudian peneliti mengusulkan model yang akan digunakan. Model tersebut berupa metode C4.5.

\section{Eksperimen dan Pengujian Model} menjabarkan bagaimana eksperimen yang dilakukan hingga terbentuknya model, serta menjelaskan cara menguji model yang terbentuk. Dataset yang sudah diolah kemudian diuji terhadap model yang sudah diusulkan.

5. Evaluasi dan validasi hasil

Setelah dilakukan pengujian model terhadap semua dataset dengan model yang diusulkan maka akan menghasilkan nilainilai akurasi dan performa. Accuracy akan dihitung dari seluruh data yang benar dibagi dengan data keseluruhan. Semakin tinggi nilai accuracy, semakin baik pula model yang dihasilkan [14]-[16]. Kemudian hasil tersebut dianalisa dan dievaluasi. Dari hasil evaluasi dapat ditarik kesimpulan dari penelitian dan eksperimen ini.

\section{Metode Penelitian}

Untuk memperoleh data yang valid dan obyektif serta memecahkan permasalahan yang telah dirumuskan, maka penulis menggunakan beberapa teknik pengumpulan data antara lain :

\subsection{Observasi}

Metode ini digunakan utuk mengamati serta mengumpulan data dari penelitian secara langsung di posyandu Desa Dames Damai Kecaman Suralaga berdasarkan fakta dan kenyataan sebenarnya.

\subsection{Dokumentasi}

Dokumentasi yaitu pengambilan data melalui dokumen tertulis maupun elekronik dari posyandu Desa Dames Damai Kecaman Suralaga, seperti KMS, sip dan dokumen-dokumen lainnya yang menunjang penelitian ini.

\subsection{Wawancara}

Metode tanya jawab langsung dengan para petugas posyandu mengenai data-data anak balita di Desa Dames Damai Kecamatan Suralaga.

\subsection{Studi Pustaka}

Dilakukan pengumpulan informasi yang dibutuhkan dengan mencari referensi-referensi yang berhubungan dengan posyandu melalui jurnal, buku-buku maupun internet.

\section{Hasil danPembahasan}

\subsection{Hasil PengolahanData}

Pengujian ini dilakukan untuk mengetahui kinerja dari metode C4.5 dalam melakukan klasifikasi terhadap status gizi balita pada Posyandu Desa Dames Damai. Proses pengujian ini dilakukan dengan Rapidminer dalam Building Block yang digunakan untuk analisis data sebagai ukuran pengujian. Dalam pengujian ini dilakukan dengan 
beberapa K-Fold Validation dari 2 - 10 K-Fold

Validation.

Dalam pengujian yang dilakukan dari K-Fold Validation 2 sampai K-Fold Validation 10 maka didapatkan nilai akurasi tertinggi pada K-Fold Validation 10 dengan accuracy, sensitivity, specificity, Ppv dan Npv.

\section{Pengujian K-Fold Validation 10}

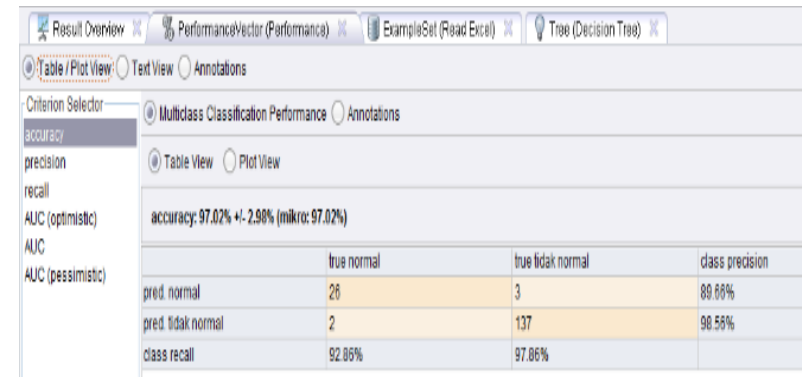

Gambar 4. Hasil Accuracy Dengan K-Fold

\section{Validation 10}

Gambar di atas merupakan hasil uji coba yang dilakukan yaitu untuk menghasilkan nilai accuracy, hasil akurasi yang diujikan adalah $97.02 \%$.

Tabel 1. Hasil Accuracy dengan K-Fold Validation 10

\begin{tabular}{|c|c|c|}
\hline Observed Class & Macet & Lancar \\
\hline Normal & 26 & 3 \\
\hline Tidak Normal & 2 & 137 \\
\hline
\end{tabular}

Jumlah True Positive (TP) adalah 26 record diprediksikan Normal, False Negatif (FN) adalah 2 record diprediksikan Normal namun Tidak Normal, Untuk False Positive (FP) adalah 3 record diprediksikan Tidak Normal namun sebenarnya Normal, dan untuk True Negatif (TN) adalah 137 record diprediksikan Tidak Normal dan benar benar Tidak Normal.

2. Hasil Pohon Keputusan (Decision Tree)

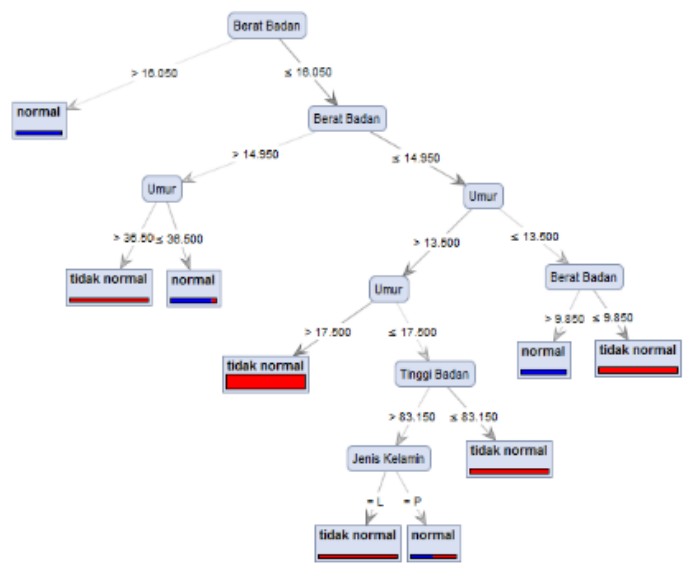

Gambar 5. Pohon Keputusan

Hasil akhir atau output dari aplikasi RapidMiner adalah berupa pohon keputusan atau decision tree. Dari pohon keputusan inilah akan dihasilkan rule atau aturan-aturan yang dapat membantu dalam mengambil keputusan dan aturan dari tree diatas adalah sebagai berikut:

1. Jika berat badan lebih dari $16 \mathrm{~kg}$ dengan umur 34-59 bulan maka dikatakan normal.

2. Jika berat badan kurang dari $16 \mathrm{~kg}$

a. Yaitu berat badan 14-16 kg dengan umur lebih dari 36 bulan maka dikatakan tidak normal.

b. Tapi jika berat badan $14-16 \mathrm{~kg}$ dengan umur kurang dari 36 bulan maka dikatakan normal.

3. Jika berat badan kurang dari atau sama dengan 14 dengan umur lebih dari 17 bulan maka dikatakan tidak normal. 
4. Jika berat badan kurang dari atau sama dengan 14 dengan umur kurang dari 17 bulan maka yang kita lihat untuk menentukan apakah dia normal atau tidak tergantung tinggi badan dan jenis kelamin.

a. Jika umurnya kurang dari 17 bulan dengan tinggi badan lebih dari $83 \mathrm{~cm}$ dengan jenis kelamin laki-laki maka dikatan tidak normal.

b. Jika umurnya kurang dari 17 bulan dengan tinggi badan lebih dari $83 \mathrm{~cm}$ dengan jenis kelamin perempuan maka dikatakan normal.

C. Jika umurnya kurang dari 17 bulan dengan tinggi badan kurang dari atau sama dengan $83 \mathrm{~cm}$ maka dikatakan tidak normal.

5. Jika umurnya kurang dari atau sama dengan 13 bulan maka untuk menentukan normal dan tidak normal dilihat dari berat badannya.

a. Jika umurnya kurang dari 13 bulan dengan berat badan lebih dari $9.8 \mathrm{~kg}$ maka dikatakan normal.

b. Sebaliknya jika umurnya kurang dari 13 bulan dengan berat badan kurang dari 9.8 kg maka dikatakan tidak normal.

AUC (Area Under Curve)

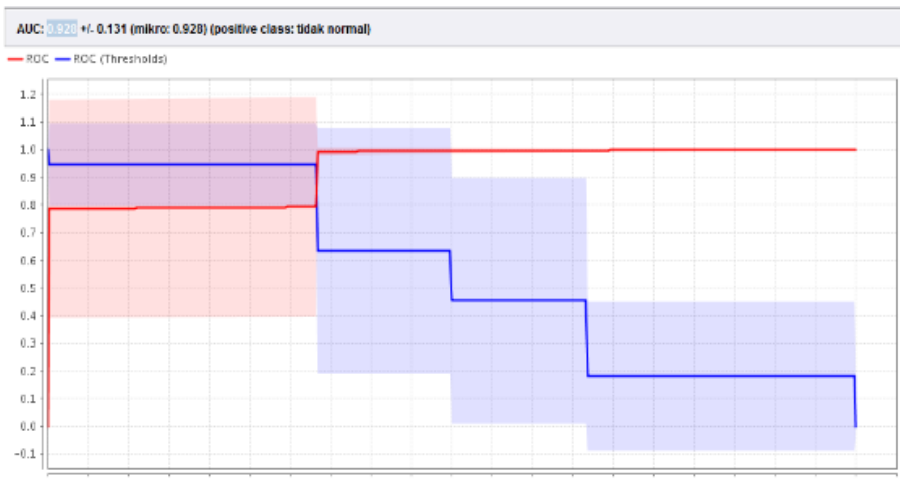

Gambar 6. Nilai AUC dalam Grafik ROC dengan K-Vod Validation 10

Gambar di atas adalah grafik ROC dengan nilai AUC (Area Under Curve) dengan hasil Accuracy dengan K-Fold Validation 10 sebesar $0.928 \%$ dengan nilai akurasi Excellent Classification (unggul/sangat baik)

\subsection{Pembahasan}

Tujuan dari penelitian ini adalah untuk menguji keakuratan metode C4.5 Decision Tree sehingga dapat digunakan dalam proses pendukung keputusan oleh pihak posyandu Desa Dames Damai. Dalam proses pengambilan keputusan untuk mengklasifikasi status gizi balita setiap bulannya. Data yang di analisis adalah semua data balita tiap bulan yang sudah valid yang diperoleh dari kader Desa Dames Damai. Dari pengujian yang dilakukan peneliti ditemukan hasil berupa pohon keputusan beserta akurasi. Untuk menguji kevalitan data maka dilakukan 10 kali pengujian sebagai berikut:

Dalam pengujian yang dilakukan dari K-Fold Validation 2 sampai K-Fold Validation 10 maka didapatkan nilai akurasi tertinggi pada K-Fold 
Infotek : Jurnal Informatika dan Teknologi

Vol. 5 No. 1, Januari 2022

Hal. 72-81

e-ISSN 2614-8773

DOI : 10.29408/jit.v5i1.4414

Link : https://dx.doi.org/10.29408/ jit.v5i1.4414

Validation 10

Tabel 2. Hasil Uji Coba K-Fold Validation 2

Sampai 10

\begin{tabular}{|c|c|c|c|c|c|}
\hline $\begin{array}{c}\text { Numbe } \\
\text { r of } \\
\text { validati } \\
\text { on }\end{array}$ & \multicolumn{5}{|c|}{ Uji Coba (Number of validation) } \\
\cline { 2 - 6 } & cy & $\begin{array}{c}\text { Sensitiv } \\
\text { ity }\end{array}$ & $\begin{array}{c}\text { Specific } \\
\text { ity }\end{array}$ & PPV & Npv \\
\hline 2 & $89,88 \%$ & $46,43 \%$ & $98,57 \%$ & $\begin{array}{c}86,67 \\
\%\end{array}$ & $\begin{array}{c}90,20 \\
\%\end{array}$ \\
\hline 3 & $95,83 \%$ & $92,86 \%$ & $96,43 \%$ & $\begin{array}{c}83,87 \\
\%\end{array}$ & $\begin{array}{c}98,54 \\
\%\end{array}$ \\
\hline 4 & $89,88 \%$ & $42,86 \%$ & $99,29 \%$ & $\begin{array}{c}92,31 \\
\%\end{array}$ & $\begin{array}{c}89,68 \\
\%\end{array}$ \\
\hline 5 & $93,40 \%$ & $71,43 \%$ & $97,86 \%$ & $\begin{array}{c}86,96 \\
\%\end{array}$ & $\begin{array}{c}94,48 \\
\%\end{array}$ \\
\hline 6 & $91,67 \%$ & $60,71 \%$ & $97,86 \%$ & $\begin{array}{c}85,00 \\
\%\end{array}$ & $\begin{array}{c}92,57 \\
\%\end{array}$ \\
\hline 7 & $95,83 \%$ & $82,14 \%$ & $98,57 \%$ & $\begin{array}{c}92,00 \\
\%\end{array}$ & $\begin{array}{c}96,50 \\
\%\end{array}$ \\
\hline 8 & $93,45 \%$ & $78,57 \%$ & $96,43 \%$ & $\begin{array}{c}81,48 \\
\%\end{array}$ & $\begin{array}{c}95,74 \\
\%\end{array}$ \\
\hline 9 & $95,87 \%$ & $92,86 \%$ & $96,43 \%$ & $\begin{array}{c}83,87 \\
\%\end{array}$ & $\begin{array}{c}98,54 \\
\%\end{array}$ \\
\hline 10 & $97,02 \%$ & $92,86 \%$ & $97,86 \%$ & $\begin{array}{c}89,66 \\
\%\end{array}$ & $\begin{array}{c}98,56 \\
\%\end{array}$ \\
\hline
\end{tabular}

Dapat disimpulkan bahwa nilai dengan hasil

terbaik yaitu terdapat pada K-Fold Validation 10 dengan nilai accuracy sebesar $97.02 \%, P p v$ sebesar $89,66 \%$, Npv sebesar $98,56 \%$, Sensitivity sebesar $92,86 \%$, Specificity sebesar $97,86 \%$ dan nilai Area Under Curve (AUC) adalah 0.928 dengan predikat Excellent Classification (klasifikasi yang sangat baik).

\section{Kesimpulan}

Berdasarkan analisis data menggunakan metode C4.5 decision tree untuk mengaanalisis status gizi balita pada posyandu Desa Dames Damai diperoleh hasil sebagai berikut:

Metode decision tree memiliki kecepatan yang tinggi dalam mengkelasifikasikan status gizi balita pada posyandu Desa Dames Damai. Hal ini dibuktikan dengan 4 atribut yang dipakai dalam pengklasifikasian yaitu jenis kelamin, umur, berat badan dan tinggi badan. Memperoleh hasil akurasi yang diperoleh sangat baik atau cukup sempurna yaitu $97.02 \%$ sedangkan nilai AUC yang diproleh dari decision tree 0.928

\section{Referensi:}

[1] Ekasari, "Konsep Dasar Posyandu," pp. 120, 2010.

[2] Y. R. W. U. Joko Purnomo, Wawan Laksito, "Aplikasi Penunjang Keputusan Penerimaan," Implementasi Algoritm. C 4.5 Dalam Pembuatan Apl. Penunjang Keputusan Penerimaan Pegawai Cv. Din. IImu, vol. 2, 2014.

[3] J. T. Informasi, A. Ridwan, P. N. Andono, C. Supriyanto, M. T. Informatika, and U. D. Nuswantoro, "Optimasi Klasifikasi Status Gizi Balita Berdasarkan Indeks Antropometri Menggunakan Algoritma Naive," Teknol. Inf., vol. 14, no. 19073380, pp. 116-126, 2018.

[4] W. Wahyudi, "Optimasi Klasifikasi Status Gizi Balita Berdasarkan Indeks Antropometri Menggunakan Algoritma C4.5 Adaboost Classification," Teknol. Inf., vol. 12, no. 2, pp. 45-51, 2019.

[5] N. Purwati, C. Agustina, and G. B. S, "Komparasi Algoritma C . 45 Dan Backpropagation Untuk Klasifikasi Status Gizi Balita Berdasarkan Indeks Antropometri Bb / U Dan BB / PB," J. 
Infotek : Jurnal Informatika dan Teknologi

Vol. 5 No. 1, Januari 2022

Hal. 72-81

e-ISSN 2614-8773

DOI : 10.29408/jit.v5i1.4414

Link : https://dx.doi.org/10.29408/ jit.v5i1.4414

Speed, vol. 9, no. 3, pp. 26-33, 2017.

[6] Y. I. Wijaya, "KLASIFIKASI TINGKAT PENGETAHUAN IBU DALAM PEMBERIAN ASI EKSKLUSIF MENGGUNAKAN ALGORITMA DECISION TREE C4.5 BERBASIS PSO," vol. 9, no. 2, pp. 125-133, 2018.

[7] D. Swanjaya, M. Kom, I. N. Farida, and M. Kom, "SISTEM PAKAR PENDETEKSI GIZI BURUK PADA ANAK MENGGUNAKAN METODE DECISSION TREE C4.5," vol. 01, no. 05, 2017.

[8] A. M. Nur and B. Harianto, "Komparasi Algoritma SVM Dan SVM Berbasis PSO Dalam Menganalisa Kinerja Guru SMAN 3 Selong," FLEPS 2019 - IEEE Int. Conf. Flex. Printable Sensors Syst. Proc., vol. 2, no. 2, pp. 86-94, 2019, doi: 10.1016/j.surfcoat.2019.125084.

[9] R. Novita, "Teknik Data Mining : Algoritma C 4 . 5," IImu Komputer.com, pp. 1-12, 2016.

[10] S. Renaldy, M. David, and A. Eka Pratiwi, "Analisis Penggunaan Daya Listrik untuk Penghematan Energi di Laboratorium Komputer Universitas Surya," J. Otomasi Kontrol dan Instrumentasi, vol. 10, no. 2, pp. 71-84, 2018, doi: 10.5614/joki.2018.10.2.1.

[11] T. D. Utama, S. W. Sihwi, and A. Doewes, "Implementasi Algoritma Iterative 